\title{
Patovyöhyke perunaseitin (Rhizoctonia solani) biologisen torjunnan tutkimuksessa
}

Paula Wilson, Eliisa Ketola ${ }^{1)}$, Paavo Ahvenniemi, Mari J. Lehtonen ja Jari Valkonen

Soveltavan biologian laitos, PL 27 (Latokartanonkaari 7), 00014 Helsingin yliopisto

${ }^{1)}$ Nykyinen osoite: Puutarhaliitto ry, Viljatie 4 C, 00700 Helsinki

Perunaseittiä aiheuttava maalevintäinen Rhizoctonia solani Kühn -sieni on moni-isäntäinen kasvipatogeeni, joka infektoi perunaa (Solanum tuberosum L.) joko siemenperunasta (seittirupi) tai maasta tulleen tartukkeen kautta. Perunaseitti heikentää satoa ja sen laatua, laskee tärkkelyspitoisuutta ja muuttaa mukulasadon kokojakaumaa. Epämuotoisten, halkeilleiden ja vihertyneiden mukuloiden osuus kasvaa. Tauti on levinnyt laajalle koko perunanviljelyalueella. Peittaus kemiallisilla torjuntaaineilla hoitaa siemenperunasta lähtöisin olevan seittitartunnan (seittirupi), mutta maalevintäiseen tartukkeeseen ei ole olemassa tehokasta torjuntaa. Suomessa maan käsitteleminen torjunta-aineilla ei ole sallittua. Maassa olevan seittitartukkeen torjunta edellyttääkin vaihtoehtoisten torjuntamuotojen, kuten esimerkiksi biologisen torjunnan kehittämistä.

Tutkimuksessa selvitettiin $R$. solanille antagonistisen Trichoderma harzianum -sienen vaikutus perunaseitin kehitykseen käyttämällä apuna maalevintäisille taudinaiheuttajille kehitettyä patovyöhykekäsitettä. Patovyöhyke on kasvin maanalaisia osia ympäröivä tilavuus, jossa sijaitessaan taudinaiheuttajan on mahdollista tartuttaa isäntäkasvi. Mitä lähempänä isäntäkasvia tartuke sijaitsee patovyöhykkeessä, sitä todennäköisempää on tartunta. Tartukkeen etäisyyden kasvaessa isäntäkasvista tartunnan todennäköisyys ja oireiden ankaruus pienenee jyrkästi. Toisaalta patovyöhykkeen koko kasvaa ajan myötä taudinaiheuttajan biomassan kasvaessa. Erilaiset torjuntamenetelmät vaikuttavat patovyöhykkeen muodostumiseen ja sen kokoon. Patovyöhyke voidaan kuvata matemaattisella mallilla, jolloin eri torjuntamenetelmien vaikutus voidaan tiivistää numeeriseen muotoon. Tämä helpottaa esimerkiksi erilaisten torjuntamenetelmien keskinäistä vertailua.

Yhdistämällä kokeellinen tutkimus kasvihuoneolosuhteissa ja patovyöhykedynamiikan matemaattinen mallintaminen, todettiin $T$. harzianumin vähentävän merkitsevästi versolaikun ankaruutta kokeen alkuvaiheessa. Myöhempinä mittauskertoina antagonistilla ei ollut vaikutusta versolaikun ankaruuteen. Tämä voi olla seurausta $T$. harzianumin siirtymisestä lisääntymisrakenteiden, kuromaitiöiden, tuottoon. Toisaalta käytettiin tartukepotentiaaliltaan erittäin korkeata seittitartuketta tartunnan varmistamiseksi ja siten ylitettiin luonnossa esiintyvät tartukemäärät. Koetulosten perusteella muodostetun patovyöhykettä kuvaavan mallin avulla voitiin päätellä, että $T$. harzianum pienensi patovyöhykkeen lopullista kokoa $48 \%$. Biotorjuntavalmisteen käyttö vähensi merkittävästi tytärmukuloiden seittirupisuutta, vihertyneisyyttä ja epämuodostuneisuutta. Myös tytärmukuloiden kokojakauma oli tasaisempi, kun antagonisti oli läsnä. Nämä tulokset viittaavat siihen, että vaikka $T$. harzianumin antagonistinen vaikutus versolaikkuun heikentyi ajan myötä, maavarsien vahingoittuminen oli vähäisempää antagonistin läsnä ollessa. Vaikutus muodostuvan mukulasadon määrään ja laatuun voi siis olla merkittävä. Jatkotutkimukset pelto-olosuhteissa ovat tarpeen biologisen torjunnan kehittämiseksi toimivaksi ja vakaaksi taudinhallintakeinoksi.

Asiasanat: perunaseitti, Rhizoctonia solani, biologinen torjunta, Trichoderma harzianum, patovyöhyke, mallintaminen. 


\section{Johdanto}

Maalevintäinen Rhizoctonia solani Kühn -sieni on moni-isäntäinen kasvipatogeeni, joka aiheuttaa perunalla (Solanum tuberosum L.) perunaseitiksi kutsuttua tautia. Perunaseitti infektoi perunaa joko siemenperunasta (seittirupi) tai maasta tulleen tartukkeen kautta (Frank \& Leach 1980; Weinhold ym. 1982). Tauti ilmenee juuristo-, varsisto- ja mukulavaurioina (Banville 1989). Se on levinnyt laajalle koko perunanviljelyalueella. Perunoiden mukuloissa tauti johtaa sadon laadun ja määrän heikentymiseen sekä mukulakoon kokojakauman muuttumiseen (Weinhold ym. 1982; Banville 1989; Read ym. 1989; Scholte 1989). Seitin aiheuttamat vauriot eivät koidu ainoastaan siemen- ja kulutusperunan tuottajien ja jalostajien tappioksi, vaan perunan huonosta laadusta kärsivät myös kuluttajat.

Siemenperunan peittaus kemiallisilla torjunta-aineilla on yleisin perunaseittiä vastaan käytetty torjuntamuoto. Peittaus on tehokas siemenperunasta lähtöisin olevaa $R$. solanin tartuketta vastaan (Bains ym. 2002; Campion ym. 2003), mutta siemenperunan peittauksen vaikutusta maalevintäiseen tartukkeeseen on tutkittu vähän. Suomessa maan käsitteleminen kemiallisilla torjunta-aineilla ei ole sallittua. Maassa olevan seittitartukkeen torjunta edellyttääkin vaihtoehtoisten torjuntamuotojen, kuten esimerkiksi maan muiden mikro-organismien antagonismiin perustuvan biologisen torjunnan kehittämistä. Biologisen torjunnan on useissa tutkimuksissa todettu vähentävän perunan versolaikkua, mukuloiden seittirupisuutta ja seittitartukkeen määrää maassa (Chand \& Logan 1984; Beagle-Ristaino \& Papavisas 1985; Tsror ym. 2001; van den Boogert \& Luttikholt 2004). Edellä mainitut perunaseitin biologista torjuntaa tutkivat kokeet ovat keskittyneet oireiden mittaamiseen kasvukauden lopussa, mukulasatoa korjattaessa. Kuitenkin perunan, seittitartukkeen ja antagonismin kehityksen kriittisten vaiheiden tuntemus on tarpeen perunaseitin biologisen torjunnan tehostamiseksi.

Epidemiologinen lähestymistapa auttaa tiivistämään taudin kehittymiseen vaikuttavat tekijät taudin leviämisen kannalta tärkeimpiin prosesseihin. Näiden prosessien yksityiskohtainen ymmärtäminen ja kvantifiointi luo perustan erilaisten torjuntamenetelmien tehostamiselle. Maalevintäisillä kasvitaudeilla, kuten perunaseitillä, taudin leviäminen voidaan jakaa alku- ja jatkotartuntoihin (Gilligan 2002). Alkutartunta tapahtuu joko siemenperunassa tai maassa säilyneen tartukkeen avulla. Jatkotartunnat leviävät joko saman kasvin eri osissa tai kasvista toiseen. Onnistuminen taudin leviämisen estämisessä riippuu mahdollisuudesta estää tai keskeyttää edellä selostettu tartuntatapahtumien ketju. Maalevintäisillä taudeilla tartuntaketjuun vaikuttavia tekijöitä, kuten eri torjuntamenetelmiä voidaan tutkia patovyöhykekäsitteen avulla (Bailey \& Gilligan 1997).

Patovyöhyke on kasvin maanalaisia osia ympäröivä tilavuus, jossa sijaitessaan taudinaiheuttajan on mahdollista tartuttaa isäntäkasvi (Gilligan 1985). Patovyöhyke ei tarkoita kasvin juuristovyöhykettä, vaan patovyöhykkeen kokoon vaikuttavat tartukkeen ominaisuudet. Mitä lähempänä isäntäkasvia tartuke sijaitsee patovyöhykkeessä, sitä todennäköisempää on tartunta. Tartukkeen etäisyyden kasvaessa isäntäkasvista tartunnan todennäköisyys pienenee erittäin jyrkästi. Mitä kauempana isäntäkasvista tartuke on, sitä suuremmassa määrin taudinaiheuttaja joutuu uhraamaan energiavarojaan kasvuun kohti isäntäkasvia ja sitä niukemmin sille jää voimavaroja tartutukseen (Gilligan \& Bailey 1997). Toinen tartunnan todennäköisyyttä vähentävä tekijä on isäntäkasvin taudinkestävyyden paraneminen sillä välin, kun taudinaiheuttaja on vasta kasvamassa kohti isäntäänsä. Toisaalta ajan kuluessa tartukkeen määrä lisääntyy taudinaiheuttajan biomassan kasvun myötä, mikä lisää tartunnan todennäköisyyttä. Patovyöhykkeessä isäntäkasvin tartunnan todennäköisyys ja oireiden ankaruus vaihtelee siis sekä tartukkeen etäisyyden että ajan suhteen. Kokeellisesti patovyöhyke määritetään etäisyytenä, jota kauempaa taudinaiheuttaja ei enää pysty tartuttamaan isäntäkasvia. Patovyöhykettä voidaan kuvata matemaattisella mallilla, jolloin tartunnan todennäköisyyteen vaikuttavat biologiset tekijät sekä todennäköisyyden muuttuminen etäisyyden ja ajan suhteen voidaan tiivistää numeeriseen muotoon (Gilligan 1985). Tämä helpottaa esimerkiksi erilaisten torjuntamenetelmien keskinäistä vertailua.

Tämän tutkimuksen tarkoituksena oli selvittää $R$. solanille antagonistisen Trichoderma harzianum -sienen vaikutus maalevintäisestä tartukkeesta lähtöisin olevan perunaseitin kehitykseen. Trichoderma-suvun sienten tiedetään toimivan $R$. solanin antagonisteina (Kubicek \& Harman 1998; Harman 2000; Howell 2003), mutta niiden käyttökelpoisuutta $R$. solanin aiheuttaman perunaseitin torjunnassa on tutkittu melko vähän. Tutkimuksessa käytettiin apuna em. patovyöhykekäsitettä. Patovyöhykkeen laajuus mitattiin kokeellisesti $T$. harzianumin läsnä ollessa ja poissa ollessa, ja sen dynamiikkaa kuvailtiin matemaattisesti. Tutkimuskysymyksiä olivat: i) vaikuttaako $T$. harzianum 
perunaseitin patovyöhykkeen muodostumiseen ja sen lopulliseen kokoon, sekä ii) vaikuttaako $T$. harzianum seittirupioireiden ankaruuteen ja sadon laatuun tytärmukuloissa?

\section{Aineisto ja menetelmät}

\section{Koejärjestelyt}

Kasvihuonekokeessa Bintje-lajikkeen minimukuloita kasvatettiin ruukuissa, joihin lisättiin perunaseittitartuke vaakatasossa eri etäisyyksille $(0,10,20 \ldots 60 \mathrm{~mm})$ perunan idusta (Kuva 1). Kasvualustana oli 2 \% Vihannes Superex -lannoiteliuoksella (N:P:K=9:5:31, Kekkilä) kostutettu kvartsihiekka (100 ml lannoiteliuosta / $1 \mathrm{~kg}$ hiekkaa, hiekan raekoko 0,5-1,2 mm, Optiroc Oy). Perunaseittitartukkeena käytettiin $R$. solanin isolaatti 11:n (AG-3) kolonisoimaa kvinoansiemen (Chenopodium quinoa L.)-hiekkaseosta (siemen : hiekka painosuhde 1:2). Posmo-perunalajikkeen versolaikkuoireesta alunperin eristetty isolaatti 11 oli osoittautunut esikokeissa voimakkaasti virulentiksi taudinaiheuttajaksi. Osassa käsittelyjä kasvualustaan lisättiin kokeen perustamisvaiheessa seittisienelle antagonistinen Trichoderma harzianum -sieni kaupallisena biotorjuntavalmisteena (4 g valmistetta $/ 1 \mathrm{~kg}$ hiekkaa, Trianum-G, Koppert, Hollanti). Koe toteutettiin $17 \pm 2{ }^{\circ} \mathrm{C}$ lämpötilassa. Vuorokauden valojakso oli $16 \mathrm{~h}$ mittainen.
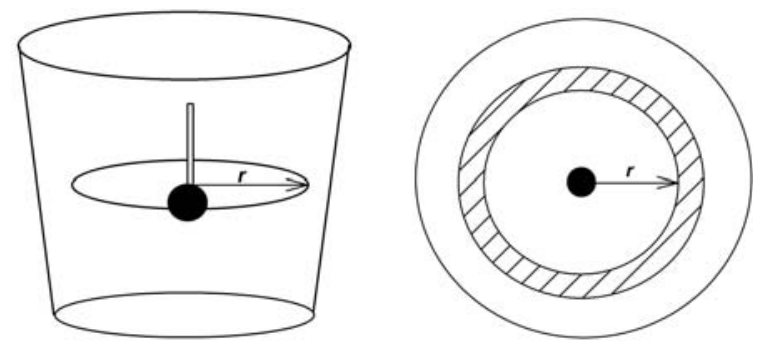

Kuva 1. Rhizoctonia solanin tartukerengas (korkeus x leveys: $10 \times 10 \mathrm{~mm}$ ) sijoitettiin vaakatasossa eri etäisyyksille $(r=0,10,20 \ldots 60 \mathrm{~mm})$ perunan idusta $(\bullet)$.

Versolaikun ankaruus mitattiin viikon välein seitsemän viikon ajan, kunnes maavarret olivat muodostuneet. Kokeen tarkkailu tapahtui useana ajankohtana, jotta biologisen torjunnan sekä seittitartukkeen ja perunan idun välisen etäisyyden vaikutusta perunaseitin kehitykseen voitiin seurata ajan suhteen. Versolaikkuoireiden ankaruus arvioitiin määrittämällä versolaikun varren tyviosasta peittämän alueen prosenttiosuus. Varren tyviosaksi määriteltiin maan pinnan alapuolella oleva lehtivihreätön osa. Versolaikkuoireiden ankaruus mitattiin Weinhold ym:n (1982) kehittämän asteikon mukaisesti: $0 \%, 1-5 \%, 6-25 \%, 26-50 \%, 51-75 \%$ tai $76-100 \%$ varren tyviosasta versolaikun peitossa. Jokaiselle kasville laskettiin keskimääräinen versolaikun ankaruus (Weinhold ym. 1982).

T. harzianumin vaikutusta tytärmukuloihin muodostuvaan seittirupeen tutkittiin koeosiossa, jossa seittitartuke lisättiin vaakatasossa yhdelle etäisyydelle $(30 \mathrm{~mm})$ perunan idusta. Koejärjestelyt olivat muutoin samanlaiset kuin versolaikkua tutkivassa koeosiossa. Seittiruven ankaruus tytärmukuloissa mitattiin mukulanmuodostuksen jälkeen (16 vko:n kuluttua kokeen perustamisesta). Seittiruven määrää mukulassa arvioitiin käyttämällä Dijstin (1985) kehittämää luokittelua: luokka 0 ei seittirupea, luokka 1 - hyvin vähän seittirupea, luokka 2 - vähän seittirupea, luokka 3 - selvästi seittiruven saastuttama ja luokka 4 - runsaasti seittirupea. Kunkin perunakasvin tytärmukuloista mitattiin tautiluokan lisäksi kunkin mukulan paino, sekä mukuloiden määä yhdessä kasvissa. Tilastollisia testejä varten seittirupiluokat 0 ja 1 , sekä 2 ja 3 yhdistettiin, sillä aineisto oli liian pieni jokaisen seittirupiluokan testaamiseksi erikseen. Seittirupiluokkaan 4 kuuluvia tytärmukuloita ei ollut lainkaan läsnä aineistossa. Tytärmukulat jaettiin painonsa mukaan viiteen luokkaan: 0,1-5,0 g; 5,1$10,0 \mathrm{~g} ; 10,1-20,0 \mathrm{~g} ; 20,1-30,0 \mathrm{~g} \mathrm{ja}>30,0 \mathrm{~g}$.

\section{Mallintaminen ja tilastolliset analyysit}

Versolaikun patovyöhykkeen muodostuminen seittitartukkeen etäisyyden ja ajan suhteen kuvattiin epälineaarisella matemaattisella mallilla. Malli on muotoa $S(r, t)=\kappa \exp \left(-\beta(t)(r-\delta)^{2}\right)$, missä $S$ on versolaikun ankaruus, $r$ on seittitartukkeen etäisyys perunan idusta, $t$ on aika (vrk), parametri $\kappa$ kuvaa 
versolaikun ankaruuden maksimiarvoa, parametri $\beta$ on käyrän kulmakerroin ja parametri $\delta$ on etäisyys, jossa versolaikun ankaruuden maksimiarvo havaitaan. Malli sovitettiin aineistoon epälineaarisella regressiolla pienimpään neliösummaan perustuen (Zar 1996). Malli sovitettiin erikseen aineistoon, jossa $T$. harzianum oli läsnä $(+T)$, ja aineistoon jossa $T$. harzianum ei ollut läsnä $(-T)$. Tällöin malli sai erilaiset parametrien $\kappa, \beta$ ja $\delta$ arvot $+T$ ja $-T$ käsittelyille. Eroja $+T$ ja $-T$ käsittelyissä parametrien arvojen suhteen testattiin nk. rinnakkaisten käyrien analyysilla (parallel curve analysis, Gilligan 1990). Jos parametrien arvoissa oli tilastollisesti merkittäviä eroja käsittelyjen suhteen, viittasi tämä siihen, että $R$. solanin patovyöhykkeen muodostuminen oli erilaista $+T \mathrm{ja}-T$ käsittelyissä.

T. harzianumin vaikutusta tytärmukuloiden painoon ja seittiruven ankaruuteen testattiin tilastollisesti $X^{2}$-testillä, ja mukuloiden määrään Mann-Whitneyn $U$-testillä.

\section{Tulokset ja niiden tarkastelu}

Versolaikun ankaruus väheni seittitartukkeen ja perunan idun välisen etäisyyden kasvaessa sekä $T$. harzianumin läsnä ollessa $(+T)$ ja poissa ollessa $(-T)$ neljän ensimmäisen mittauskerran aikana (Kuva 2). Myöhempinä mittauskertoina versolaikun ankaruus kasvoi jonkin verran etäisyyden kasvaessa molemmissa käsittelyissä. Tämän tuloksen selittää se, että kauemmilla etäisyyksillä sijainnut suurempi seittitartukemäärä saavutti perunan idun ajan kuluessa. T. harzianum vähensi $R$. solanin aiheuttaman versolaikun ankaruutta ensimmäisen mittauskerran ( 7 vrk) aikana (eroja parametri $\beta$ :ssa käsittelyjen kesken, $F_{(1,136)}=7,44, \mathrm{p}<0,05$, kuva 2). Erityisesti antagonisti vähensi versolaikun ankaruutta seittitartukkeen sijaitessa $>30 \mathrm{~mm}$ päässä idusta. Myöhempinä mittauskertoina antagonistilla ei ollut vaikutusta versolaikun ankaruuteen (Kuva 2). Tämä voi olla seurausta $T$. harzianumin siirtymisestä lisääntymisrakenteiden, kuromaitiöiden, tuottoon aktiivisen vegetatiivisen kasvun sijaan (Papavizas 1985). Toisaalta käytettiin tartukepotentiaaliltaan erittäin korkeata seittitartuketta tartunnan varmistamiseksi ja siten ylitettiin luonnossa esiintyvät tartukemäärät. Koetulosten perusteella muodostetun patovyöhykettä kuvaavan mallin avulla voitiin päätellä, että $T$. harzianum vähensi patovyöhykkeen kokoa $48 \%$ (Kuva 3).
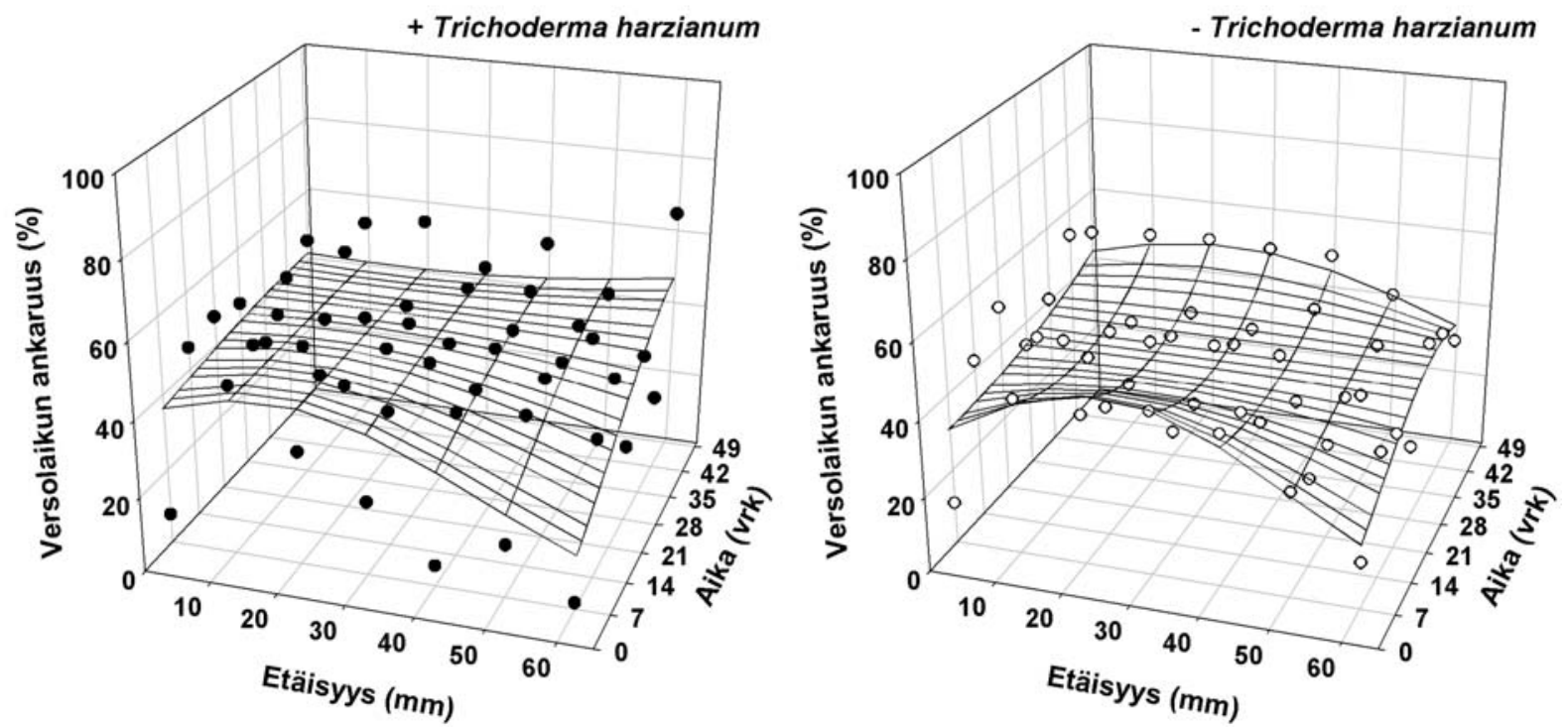

Kuva 2. R. solanin patovyöhykkeen muodostuminen tartukkeen ja perunan idun välisen etäisyyden sekä ajan suhteen T. harzianumin läsnä ollessa ja poissa ollessa. Symbolit $\bullet$ ja $\circ$ kuvaavat kasvihuonekokeessa mitattua aineistoa. Patovyöhykettä kuvaava malli $S(r, t)=\kappa \exp \left(-\beta(t)(r-\delta)^{2}\right)$ on esitetty verkkona. 


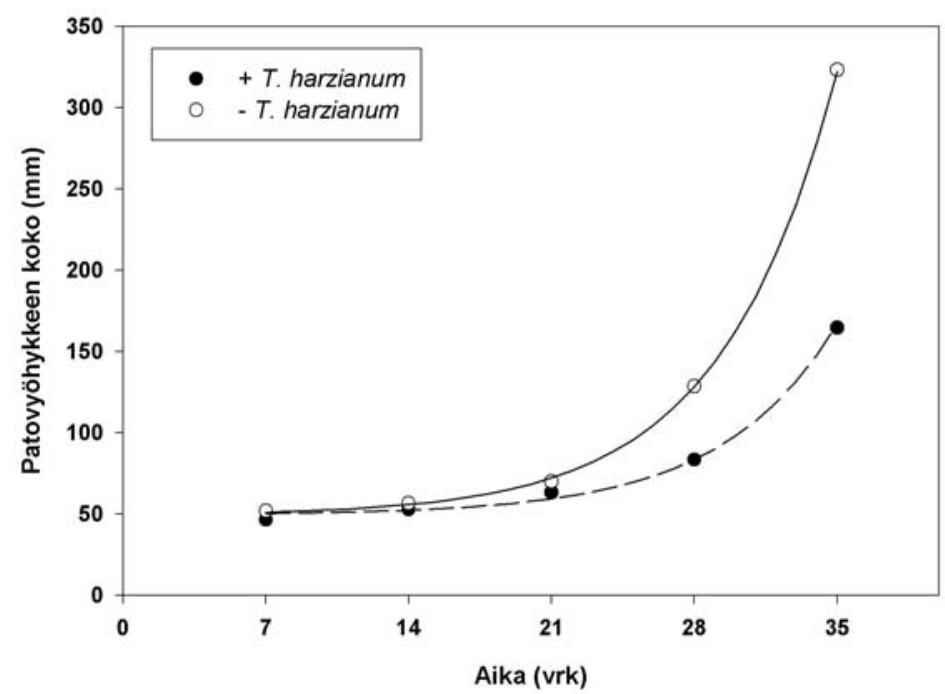

Kuva 3. R. solanin patovyöhykkeen laajuuden muutos ajan myötä T. harzianumin läsnä ollessa ja poissa ollessa.

T. harzianum vähensi merkittävästi tytärmukuloiden seittirupisuutta $\left(X^{2}=12,547\right.$, d.f. $\left.=1, p<0,001\right)$ (Kuva 4a), sekä tytärmukuloiden keskimääräistä lukumäärää yhtä kasvia kohden $(+T: 6,5 \pm 1,1$ mukulaa/kasvi; $-T: 9,9 \pm 2,7$ mukulaa/kasvi, $\left.U_{(0,05,18)}=18,50, \mathrm{p}<0,05\right)$. Myös tytärmukuloiden painoluokkiin jakautumisessa oli eroja $+T$ ja $-T$ käsittelyjen välillä $\left(X^{2}=17,505\right.$, d.f. $\left.=4, \mathrm{p}<0,01\right)$. Tytärmukuloiden kokojakauma oli tasaisempi, kun antagonisti oli läsnä. Erityisesti pienimpään kokoluokkaan $(0,1-5,0 \mathrm{~g})$ kuuluvia mukuloita oli enemmän T. harzianumin poissa ollessa (Kuva 4b). Lisäksi T. harzianumin poissa ollessa tytärmukulat olivat epämuotoisia ja vihertyneitä.

(a)

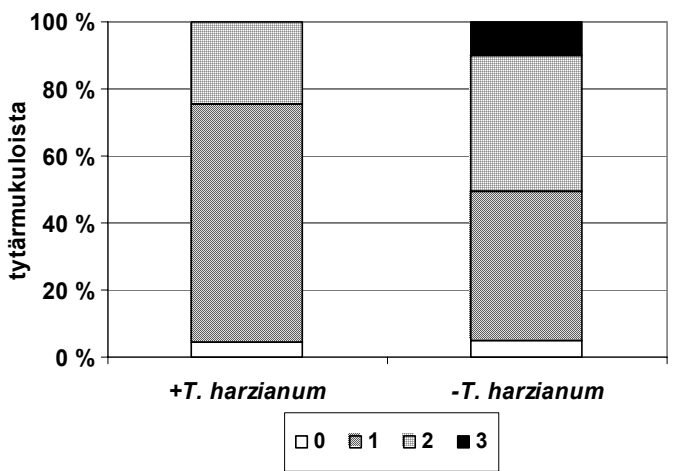

(b)

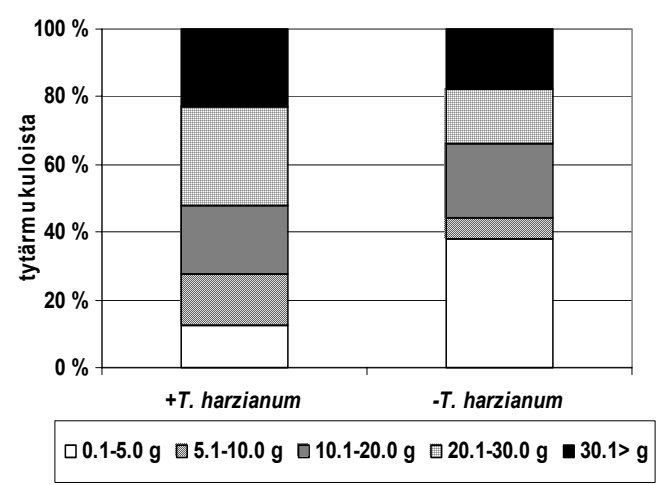

Kuva 4. Tytärmukuloiden (a) seittiruven ankaruus ja (b) kokojakauma T. harzianumin läsnä ollessa ja poissa ollessa.

\section{Johtopäätökset}

Suunniteltaessa kasvitautien torjuntaa on tärkeää muistaa, että onnistunut torjunta saavutetaan vaikuttamalla paikalliseen, kasviyksilötason infektiotapahtumaan. Tämä heijastuu edelleen muutoksina epidemian etenemisessä kasvipopulaatiotasolla. Patovyöhykekäsitteen avulla voidaan kasviyksilötasolla selvittää, mihin taudin leviämisen kannalta tärkeisiin epidemiologisiin prosesseihin (alku- ja jatkotartunnat) torjunnalla on vaikutusta. Käsite ottaa huomioon muutokset taudin kehityksessä sekä ajallisesti että paikallisesti.

Maasyntyisestä tartukkeesta lähtöisin olevan perunaseitin biologista torjuntaa tutkittiin patovyöhykekäsitteen avulla. Saadut tulokset viittaavat siihen, että vaikka $T$. harzianumin antagonistinen vaikutus versolaikun ankaruuteen heikentyi ajan myötä, torjunta pienensi patovyöhykkeen lopullista kokoa. Myös maavarsien vahingoittuminen ja seittirupipahkojen 
muodostuminen oli vähäisempää antagonistin läsnä ollessa. Vaikutus muodostuvan mukulasadon määrään ja laatuun voi siis olla merkittävä.

Jatkotutkimukset pelto-olosuhteissa ovat käynnistyneet perunaseitin biologisen torjunnan kehittämiseksi toimivaksi ja vakaaksi taudinhallintakeinoksi. Lisäksi biotorjuntavalmisteen käytön vaikutus seittisienen infektioprosessiin erityisesti maavarsissa selvitetään yksityiskohtaisesti kasvihuonekokeissa. Tavoitteena on muodostaa kokeellisten tulosten ja mallintamisen avulla epidemiologien teoriatausta perunaseitin torjunnan tehostamiseksi.

\section{Kirjallisuus}

Bailey, D. J. \& Gilligan, C. A. 1997. Biological control of pathozone behaviour and disease dynamics of Rhizoctonia solani by Trichoderma viride. New Phytol. 136: 359-367.

Bains, P. S., Bennypaul, H. S., Lynch, D. R., Kawchuk, L. M. \& Schaupmeyer, C. A. 2002. Rhizoctonia disease of potatoes (Rhizoctonia solani): Fungicidal efficacy and cultivar susceptibility. Amer. J. Potato Res.79:99-106.

Banville, G. J. 1989. Yield losses and damage to potato plants caused by Rhizoctonia solani Kühn. Am. Potato J. 66: 821-834.

Beagle-Ristaino, J. E. \& Papavizas, G. C. 1985. Biological control of Rhizoctonia stem canker and black scurf of potato. Phytopathol. 75:560-564.

van den Boogert, P. H. J. F. \& Luttikholt, A. J. G. 2004. Compatible biological and chemical control systems for Rhizoctonia solani in potato. Eur. J. Plant Pathol. 110:111-118.

Campion, C., Chatot, C., Perraton, B. \& Andrivon, D. 2003. Anastomosis groups, pathogenicity and sensitivity to fungicides of Rhizoctonia solani isolates collected on potato crops in France. Eur. J. Plant Pathol. 109: 983-992.

Chand, T. \& Logan, C. 1984. Antagonists and parasites of Rhizoctonia solani and their efficacy in reducing stem canker of potato under controlled conditions. Trans. Br. Mycol. Soc. 83:107-112.

Dijst, G. 1985. Investigations on the effect of haulm destruction and additional root cutting on black scurf on potato tubers. Neth. J. Plant Pathol. 91: 153-162.

Frank, J. A. \& Leach, S. S. 1980. Comparison of tuberborne and soilborne inoculum in the Rhizoctonia disease of potato. Phytopathol. 70: 51-53.

Gilligan, C. A. 1990. Comparison of disease progress curves. New Phytol. 115: 223-242.

Gilligan, C. A. 1985. Probability models for host infections by soilborne plant pathogens. Phytopathol. 75: 6167.

Gilligan, C. A. 2002. An epidemiological framework for disease management. Adv. Bot. Res. 38:1-64.

Gilligan, C. A. \& Bailey, D. J. 1997. Components of pathozone behaviour. New Phytol. 136:343-358.

Harman, G. E. 2000. Myths and dogmas of biocontrol. Changes in perceptions derived from research on Trichoderma harzianum T-22. Plant Dis. 84:377-393.

Howell, C. R. 2003. Mechanisms employed by Trichoderma species in the biological control of plant diseases: the history and evolution of current concepts. Plant Dis. 87: 4-10.

Kubicek, C. P. \& Harman, G. E. 1998. Trichoderma and Gliocladium. Vol. 1. Basic biology, taxonomy and genetics. Lontoo: Taylor \& Francis.

Papavizas, G. C. 1985. Trichoderma and Gliocladium: biology, ecology, and potential for biocontrol. Ann. Rev. Phytopathol. 23:23-54.

Read, P. J., Hide, G. A., Firmager, J. P. \& Hall, S. M. 1989. Growth and yield of potatoes as affected by severity of stem canker (Rhizoctonia solani). Potato Res. 32: 9-15.

Scholte, K. 1989. Effects of soil-borne Rhizoctonia solani Kühn on yield and quality of ten potato cultivars. Potato Res. 32: 367-376.

Tsror, L., Barak, R. \& Sneh, B. 2001. Biological control of black scurf on potato under organic management. Crop Prot. 20: 145-150.

Weinhold, A. R., Bowman, T. \& Hall, D. H. 1982. Rhizoctonia disease of potato - effect on yield and control by seed tuber treatment. Plant Dis. 66: 815-818.

Zar, J. H. 1996. Biostatistical analysis. 3. painos. New Jersey: Prentice Hall. 